\title{
Puddling of butterflies in Jahangirnagar University campus and the bank of Bangshi river, Savar, Bangladesh
}

\author{
Nourin Rima, Afroza Meme and Md. Monwar Hossain* \\ Department of Zoology, Jahangirnagar University, Savar, Dhaka-1342, Bangladesh
}

\begin{abstract}
Butterfly is one of the amazing creatures of nature, which possesses some interesting behavior like puddling that includes feeding at mud, dung or carrion. A total of 54 species of butterflies under 8 families were found to gather around two different puddle grounds viz. Jahangirnagar University campus (JU campus) and bank of Bangshi river (BBR), Savar, Dhaka during January 2012 to December 2013. Among the recorded 54 species of butterflies, 6 species belonged to the family Papilionidae, 11 species to Pieridae, 10 species to Lycaenidae, 3 species to Danaidae, 13 species to Nymphalidae, 7 species to Satyridae, 3 species to Hesperiidae and 1 species to Acraeidae. In JU campus several types of puddling sources were used by butterflies viz. mud or wet soil, dung, carrion, wet sands and wet bricks, human sweat, bird-dropping, rotten fruits and flowers. On the other hand, in the bank of Bangshi river, butterflies used polluted water on the river side. In those puddle sources, members of Papilionidae and Pieridae were preferred mineral sources as they did puddle on mostly water sources (mud, wet soil, wet sand, wet brick), while members of Nymphalidae, Hesperiidae and Lycaenidae preferred to puddle on various nutrient sources (carrion, dung, rotten flowers). These results indicated that butterfly require various minerals and nutrients which are extracted through puddling sources for their reproductive success and other physiological activities.
\end{abstract}

Key words: Puddling, Butterfly, Jahangirnagar University campus, Bangshi river

\section{INTRODUCTION}

Butterflies play an important role in ecosystem. It is used in pollination, as a food source for other species and an important connector in a flourishing ecosystem web (http://www.onegreenplanet.org/environment/how-the-butterfly-can-shape-an-ecosystemand-why-we-need-to-protect-them/ accessed on 10.06.16). The greatest economic importances of butterflies come from their function as pollinators of crops. They offer particularly valuable contribution to the genetic diversity of any ecosystem. Nevertheless, where bees tend to be home based, butterflies move randomly over the landscape. Certain plants such as the Blazing star and Curtis milkweed are totally dependent on butterflies for pollination (Candice 2005). The vibrant colors of big flowers that attract butterflies have a landing platform (labellum) and gather pollen on their long, thin legs as they sip nectar from a flower (http://www.ehow.com/facts_5744686_role-butterfliesecosystem.html accessed on 10.06.16). Butterflies feed primarily on nectar from flowers. Some also derive nourishment from pollen (Gilbert, 1972). Besides, butterfly sipping water along with minerals by feeding at mud, dung, carrion or water (Arms et al., 1974,

*Corresponding author. E-mail: zona444@yahoo.com 
Adler, 1982, Adler \& Pearson, 1982, Beck et al., 1999, Rima, 2012, Meme, 2014). This is an amazing behavior called puddling by butterflies in nature (Boggs \& Jackson, 1991). Besides, even the sweat on human skin may also attract the butterflies. On sunny days, after rain butterfly gather for puddle. The main reason for visiting puddle is to get nutrients mainly sodium (Na) (Arms et al., 1974, Pivnick \& McNeil, 1987, Smedley \& Eisner, 1995, 1996). Besides, up taking Sodium, they also get other nutrients like amino acids (Arms et al., 1974, Boggs \& Gilbert, 1979) and other salts like calcium phosphate (Lai-Fook 1991). The butterflies puddle for several seconds to an hour at a time. All this behavior leads up to the main purpose of a butterfly's life-reproduction. Usually male butterflies visit puddling and transfer those nutrients to females during copulation along with spermatophore as a nuptial gift (Drummond 1984, Beck et al., 1999).

In JU campus, about 115 species of butterflies were recorded out of possible 325 species of butterflies in Bangladesh (Ameen \& Chowdhury, 1968, Choudhury \& Zethner, 1971, Bashar, 2014, Baksha \& Choudhury, 1983, 1985, Ahmed \& Islam, 1987, Alam \& Ullah 1995, Shaheduzzaman, 1998, Chowdhury \& Mohiuddin, 2003, Hossain et al., 2003, Razzak et al, 2007, Shefa \& Hossain, 2010, Chowdhury \& Hossain, 2013, Bashar, 2014, Neogi et al., 2014, Akter et al.,2015, Hossain et al., 2015). Now a day's massive habitat destruction like, urbanization, cut of trees for fuel, and overall pollution or environmental changes, like heating, storm, changes water qualities by industrial effluent may impact on butterfly physiological and reproductive success. Therefore, present study is focused on those species, which are involved in puddling in Jahangirnagar University campus (JU campus) and the bank of Bangshi river (BBR) at savar area, Bangladesh. In addition, different types of puddling sources were also enlisted in this study because, overall pollution and climatic changes has impact on soil and water qualities of the puddle sources that may influences various biological activities of butterflies.

\section{MATERIALS AND METHODS}

Butterflies were observed carefully in different puddling grounds / sources of JU campus and bank of Bangshi river areas during January, 2012- December, 2013 (Fig. 2a-h). The puddling behavior of butterflies on moist substances was studied. The mud or wet soil, dung, carrion, wet sand and wet brick, human sweat, bird-dropping, rotten fruits and flowers are the rich source of minerals and nutrients. The butterflies were observed from a little distance and photographs (Camera: Canon 7D) were taken carefully without interrupting their activities. Butterflies were captured with the help of insect net and identification of butterflies were done up to family level using the Keys of Borror et al., (1981), up to generic and species level using the keys of Bingham $(1905,1907)$, WynterBlyth (1957) and Talbot (1978 a,b).

\section{RESULTS AND DISCUSSION}

A total of 54 species of butterflies under 8 families were found to gather around two different puddle grounds viz. Jahangirnagar University campus (JU campus) and bank of Bangshi river (BBR), savar, Dhaka during January, 2012- December, 2013. Among the 
recorded 54 species of butterflies, 6 species belonged to the family Papilionidae, 11 species to Pieridae, 10 species to Lycaenidae, 3 species to Danaidae, 13 species to Nymphalidae, 7 species to Satyridae, 3 species to Hesperiidae and 1 species to Acraeidae (Table 1). Puddling of butterflies among different families is described below:

\section{Family: Papilionidae}

A total of 6 species under Papilionidae were recorded around the puddle (Table 1). Common mime, Common mormon and Lime butterfly were engaged in puddling on lake side water (mud), wet soil and wet sand (Fig. 1a). Besides, Common jay, Common bluebottle and Common rose were puddle on wet soil and wet sand (Fig. 1b) (Table 1). In addition, Common bluebottle and Common rose were preferred puddle on mud.

\section{Family: Pieridae}

A total of 11 species under this family were found to puddle (Table 1). Common grass yellow was most common throughout the study period and this species was found highest in number at a time to gather around dung, mud, wet brick and soil (Fig 1c). Dung is also preferred by Three-spot grass yellow, Mottled emigrant and Chocolate albatross. Besides, Painted jezebel, Common jezebel, Psyche, Common gull and Great orange tip were preferred to puddle over wet soil (Table 1). In addition, Common emigrant was found to puddle at mud, wet sand and brick (Fig 1d) while Striped albatross was found on rotten fruits and wet sand (Table 1).

\section{Family: Lycaenidae}

A total of 10 species of Lycaenid butterfly were recorded in puddling sources (Table 1). Among them, Common pierrot, Angled pierrot, Spotted pierrot and Common lineblue were engaged around dung, mud and wet soil (Fig. 1ef). Besides, Common pierrot and Spotted pierrot were also found in carrion. Lime Blue, Tailless lineblue, Gram blue, Yamfly and Quaker were involved in puddle on wet soil (Fig. 1g) while Quaker also preferred to bird dropping (Table 1). On the other hand, only Lesser grass blue was found to gather in rotten flowers (Table 1).

\section{Family: Danaidae}

Only 3 species were recorded under this family (Table 1). Plain tiger was found in dung and mud while Striped tiger was found in carrion and wet soil respectively (Fig 1h). Besides, Common crow was puddle in mud (Table 1).

\section{Family: Nymphalidae}

A total of 13 species of Nymphalid butterfly were recorded in this phenomenon (Table 1). Among them Great eggfly, Common sergeant, Common sailer and Commander were found to gather around mud and rotten fruits (Fig 1i) while Black rajah, Common leopard, Lemon pansy, Leopard lacewing and Commander were found in wet soil (Fig. 1j). On the other hand, Grey pansy and Peacock pansy were found to puddle around dung, mud and wet soil (Fig 1k), as well as Common baron was found to puddle over human sweat, bird dropping and lake side water (mud). Gaudy baron, a unique butterfly was found in rotten fruits and wet sand whereas Common castor was found to puddle on rotten fruits and rotten flowers (Table 1). 


\section{Family: Satyridae}

A total of 7 species of Satyrid butterfly were recorded in puddling (Table 1). Among them Common evening brown and Dark evening brown were most frequent and found on carrion, rotten fruits and flowers as well as wet soil (Fig. 11). Sometimes Lephca bushbrown, Common bushbrown and Dark branded bushbrown were found to puddle on wet soil. Besides Common bushbrown was preferred to gather around carrion while Darkbranded bushbrown preferred rotten fruits (Fig. 1m). On the other hand, Common palmfly was preferred to carrion and bird dropping while Spotted palmfly preferred to puddle on dung and wet soil (Table 1).

\section{Family: Hesperiidae}

Only 3 species of butterfly under this family were recorded to involve in puddling (Table 1). These were Grass demon, Tree flitter and Chestnut angle. Grass demon and Tree flitter were found to gather on bird dropping and rotten flowers, while Tree flitter was also observed for puddle in human sweat (Fig. 1no). Only Chestnut angle was found to puddle in wet soil.

\section{Family: Acraeidae}

Only 1 species, Tawny coster was recorded to involve in puddling under this family (Table 1). It was found for puddle in wet sand (Fig. 1p).

In the present study several types of puddling sources were documented in Jahangirnagar University campus (JU campus) while in the bank of Banshi river only one type (but two different sites) of puddling sources were documented. Description of these different puddling sources is given below:

\section{JU Campus}

Mud or Wet soil: This was mostly seen just after a rain in JU campus. Common grass yellow, Common emigrant, Common mime, Common mormon, Commander, Common leopard, Common evening brown and Common bushbrown were found visiting such muddy places or wet soil and acquiring their needed minerals and nutrients from these sources during the study period (Fig. 2ab) (Table 1).

Dung: Cattle manure is basically made up of digested grass and grain. This is high in organic materials and rich in nutrients. The accumulation of dung was observed in the botanical garden of Biological faculty, JU and in front of Students' hall, JU that were kept for gardening as bio-fertilizer (Fig 2c). Common grass yellow, Three-spot grass yellow, Mottled emigrant, Common pierrot, Angled pierrot, Common lineblue, Grey pansy, Peacock pansy and Plain tiger were commonly seen puddling on dung (Fig. 1fh) (Table 1). It was recorded that butterflies used to puddle on fresh dung as well as on compost dung.

Lake side water (mud): Water of lake side of JU campus is a very common source for puddling of butterflies (Fig 2d). Common mime, Common mormon, Lime butterfly and 
Common baron were commonly seen to puddle over water of different lakes in the campus (Table 1).

Carrion: The leftover of fruits and vegetables in the dustbin and on nearby the road were seen to supply popular source for puddling of butterflies (Fig. 2e). Butterflies of the family Lycaenidae, Danaidae, Nymphalidae and Satyridae were seen on this carrion (Table 1).

Wet sand and wet brick: Sometimes sand and brick were kept in JU campus for construction works which was also used for puddling of butterflies (Fig. 2f). When sand and brick were wet by any means of water can also be attracted by butterflies in these grounds. Mostly member of the family Papilionidae, Pieridae, Nymphalidae and Acraeidae were found visiting these places (Fig. 1bdp) (Table 1).

Human sweat: It was seen that human sweat was also attractive to the butterflies. In dam weather with high humidity when more sweating occurs, Tree flitter was seen to puddle on human skin (Fig. 10).

Bird-dropping: In JU campus so many birds are resided and they have faces accordingly. Bird-drop is enriched with nitrogen, as they are uricotelic, excrete nitrogenous waste in the form of urea which is composed of ammonia. Butterflies like Quaker, Common baron, Common palmfly, Grass demon and Tree flitter were attracted to these bird-drops mainly for ammonia in the JU campus (Fig. 1n) (Table 1).

Rotting flowers and fruits: Fruit juices are rich in sugar and provided a good source of nutrients to butterfly. In addition, rotten leaves and flowers are also good sources of various nutrients. Members of Pieridae, Nymphalidae, Satyridae and Hesperiidae were found to gather around rotten fruits and flowers (Fig. 1m) (Table 1).

\section{Bank of Bangshi River}

Puddling behavior of butterflies were recorded in two different sites of Bangshi river viz. a joining point of narrow canal to the river (site 1), coming from Pakija Dyeing Industry area and at the site where this narrow branch goes for some kilometers and turning ' $U$ ' connected with wide branch (site 2) (Fig. 2gh). Water of this river side is a very common source for puddling for butterflies like Common mormon, Lime butterfly, Common grass yellow, Common emigrant, Common jezebel, Angled pierrot, Gram blue, Grey pansy, Common sailer, Common baron, Common bushbrown, Common evening brown and Chestnut angle (Table 1).

In the present study 54 species of butterflies under the family Papilionidae, Pieridae, Danaidae, Lycaenidae, Nymphalidae, Satyridae, Hesperiidae and Acraeidae were found to involve in puddling (Table 1). Among the diverse puddle sources, mud, wet soil, wet sand, dung, carrion and bird dropping are common in study areas (Fig. 2a-h). As a puddle source dung was the most favorites besides mud and wet soil for many butterflies (Fig. 1fh) (Table 1) (Boggs \& Jackson 1991). Researchers showed that different families of 
butterflies have preference of up-taking various salts and amino acids from various puddle sources. Members of Papilionidae and Pieridae more often visited $\mathrm{NaCl}$ rich sources and members of Nymphalidae, Hesperiidae and Lycaenidae preferred amino acid rich sources (Beck et al., 1999, Lai-Fook 1991, Pivnick \& McNeil, 1987, Smedley \& Eisner, 1995, 1996). In the present study results showed that the members of Papilionidae and Pieridae were preferred mineral sources as they did puddle on mostly water sources (mud, wet soil, wet sand, wet brick) while members of Nymphalidae, Hesperiidae and Lycaenidae were preferred to puddle on various nutrient sources (carrion, dung, rotten flowers) (Gilbert 1972, Alm et al., 1990, Erhardt \& Rusterholz 1998, O'Brien et al., 2005). These results are indicated that butterfly requires various minerals and nutrients which are extracted through puddling for their reproductive success and physiological activities (Adler \& Pearson, 1982, Pivnick \& McNeil, 1987, Smedley \& Eisner, 1996).

Numerous species of butterflies regularly visited decaying fruits and flowers. This behavior is mainly opportunistic, though some are highly attracted to rotten fruits (Hamer et al., 2006). Rotting fruits make sugar available to butterflies and their derivatives such as alcohols, which are mainly useful as carbohydrates, fuel for ATP production (DeVries $\&$ Walla, 2001). The leftovers of fruits and vegetables can be a rich source of nutrients for butterfly when doing puddling on them. In the present study several unusual puddling sources were also identified i.e. decaying fruits, human sweat, rotting flowers, bird drops etc. (Fig. 1mno).

Climatic changes have direct impact on soil and water qualities that badly affects the puddling sources. Disruption of puddling sources will hamper the life cycle of butterfly. Therefore, in the future research, how climate change affects butterflies remains to be explored.

Table 1. Incidence of Puddling of Butterflies in JU campus and Bank of Bangshi river (BBR)

\begin{tabular}{|c|c|c|c|c|}
\hline Sl. No & Name of Butterfly & \multicolumn{2}{|c|}{ Puddling Site } & \multirow[t]{2}{*}{ Puddling Sources } \\
\hline \multicolumn{2}{|r|}{ Papilionidae } & $\begin{array}{c}\text { JU } \\
\text { Campus }\end{array}$ & BBR & \\
\hline 01 & Common mime (Papilio clytia) & $\sqrt{ }$ & $x$ & $\begin{array}{l}\text { Lake side water (mud), Mud, } \\
\text { Wet soil, Wet sand }\end{array}$ \\
\hline 02 & $\begin{array}{l}\text { Common mormon (Papilio } \\
\text { polytes) }\end{array}$ & $\sqrt{ }$ & $\sqrt{ }$ & $\begin{array}{l}\text { Lake side water (mud), Wet } \\
\text { soil, Wet sand }\end{array}$ \\
\hline 03 & $\begin{array}{l}\text { Lime butterfly (Papilio } \\
\text { demoleus) }\end{array}$ & $\sqrt{ }$ & $\sqrt{ }$ & $\begin{array}{l}\text { Lake side water (mud), Wet } \\
\text { soil, Wet sand }\end{array}$ \\
\hline 04 & Common jay (Graphium doson) & $\sqrt{ }$ & $x$ & Wet soil, Wet sand \\
\hline 05 & $\begin{array}{l}\text { Common bluebottle (Graphium } \\
\text { sarpedon) }\end{array}$ & $\sqrt{ }$ & $x$ & Mud, Wet soil \\
\hline 06 & $\begin{array}{l}\text { Common rose } \\
\text { (Pachliopta aristolochiae) }\end{array}$ & $\sqrt{ }$ & $\times$ & Mud, Wet soil, Wet sand \\
\hline \multicolumn{5}{|c|}{ Pieridae } \\
\hline 07 & $\begin{array}{l}\text { Common grass yellow (Eurema } \\
\text { hecabe) }\end{array}$ & $\sqrt{ }$ & $\sqrt{ }$ & Dung, Mud, Wet brick, Wet soil \\
\hline
\end{tabular}




\begin{tabular}{|c|c|c|c|c|}
\hline 08 & $\begin{array}{l}\text { Three-spot grass yellow } \\
\text { (Eurema blanda) }\end{array}$ & $\sqrt{ }$ & $x$ & Dung, Wet soil \\
\hline 09 & $\begin{array}{l}\text { Common emigrant (Catopsilia } \\
\text { pomona) }\end{array}$ & $\sqrt{ }$ & $\sqrt{ }$ & Mud, Wet sand, Wet brick \\
\hline 10 & $\begin{array}{l}\text { Mottled emigrant (Catopsilia } \\
\text { pyranthe) }\end{array}$ & $\sqrt{ }$ & $x$ & Dung, Wet sand, Wet brick \\
\hline 11 & $\begin{array}{l}\text { Painted jezebel (Delias } \\
\text { hyparete) }\end{array}$ & $\sqrt{ }$ & $\times$ & Wet soil \\
\hline 12 & $\begin{array}{l}\text { Common jezebel (Delias } \\
\text { eucharis) }\end{array}$ & $\sqrt{ }$ & $\sqrt{ }$ & Wet soil \\
\hline 13 & $\begin{array}{l}\text { Striped albatross (Appias } \\
\text { libythea) }\end{array}$ & $\sqrt{ }$ & $\times$ & Rotten fruits, Wet sand \\
\hline 14 & $\begin{array}{l}\text { Chocolate albatross (Appias } \\
\text { lyncida) }\end{array}$ & $\sqrt{ }$ & $\times$ & Dung, Mud \\
\hline 15 & Psyche (Leptosia nina) & $\sqrt{ }$ & $\times$ & Wet soil \\
\hline 16 & Common gull (Cepora nerissa) & $\sqrt{ }$ & $x$ & Wet soil \\
\hline 17 & $\begin{array}{l}\text { Great Orange-tip (Hebomoia } \\
\text { glaucippe) }\end{array}$ & $\sqrt{ }$ & $x$ & Mud, Wet soil \\
\hline \multicolumn{5}{|c|}{ Lycaenidae } \\
\hline 18 & $\begin{array}{l}\text { Common pierrot (Castalius } \\
\text { rosimon) }\end{array}$ & $\sqrt{ }$ & $x$ & Carrion, Dung, Mud, Wet soil \\
\hline 19 & Angled pierrot (Caleta decidia) & $\sqrt{ }$ & $\sqrt{ }$ & Dung, Wet soil \\
\hline 20 & $\begin{array}{l}\text { Spotted pierrot (Tarucus } \\
\text { callinara) }\end{array}$ & $\sqrt{ }$ & $x$ & Carrion, Mud, Wet soil \\
\hline 21 & Lesser grass blue (Zizina otis) & $\sqrt{ }$ & $x$ & Rotten flowers \\
\hline 22 & Lime blue (Chilades lajus) & $\sqrt{ }$ & $x$ & Wet soil \\
\hline 23 & $\begin{array}{l}\text { Tailless lineblue (Prosotas } \\
\text { dubiosa) }\end{array}$ & $\sqrt{ }$ & $x$ & Wet soil \\
\hline 24 & $\begin{array}{l}\text { Common lineblue (Prosotas } \\
\text { nora) }\end{array}$ & $\sqrt{ }$ & $\times$ & Dung, wet soil \\
\hline 25 & Gram blue (Euchrysops cnejus) & $\sqrt{ }$ & $\sqrt{ }$ & Wet soil \\
\hline 26 & Yamfly (Loxura atymnus) & $\sqrt{ }$ & $x$ & Wet soil \\
\hline 27 & Quaker (Neopithecops zalmora) & $\sqrt{ }$ & $\times$ & Bird dropping, Wet soil \\
\hline \multicolumn{5}{|c|}{ Danaidae } \\
\hline 28 & Plain tiger (Danaus chrysippus) & $\sqrt{ }$ & $\times$ & Dung, Mud \\
\hline 29 & Striped tiger (Danaus genutia) & $\sqrt{ }$ & $x$ & Carrion, Wet soil \\
\hline 30 & Common crow (Euploea core) & $\sqrt{ }$ & $x$ & Mud \\
\hline \multicolumn{5}{|c|}{ Nymphalidae } \\
\hline 31 & Great eggfly (Hypolimnas bolina) & $\sqrt{ }$ & $x$ & Mud, Rotten fruits \\
\hline 32 & Black rajah (Charaxes solon) & $\sqrt{ }$ & $\times$ & Wet soil \\
\hline 33 & $\begin{array}{l}\text { Common leopard (Phalanta } \\
\text { phalantha) }\end{array}$ & $\sqrt{ }$ & $x$ & Mud, Wet soil \\
\hline 34 & Grey pansy (Junonia atlites) & $\sqrt{ }$ & $\sqrt{ }$ & Dung, Mud, Wet soil \\
\hline 35 & Peacock pansy (Junonia almana) & $\sqrt{ }$ & $x$ & Dung, Mud, Wet brick \\
\hline 36 & Lemon pansy (Junonia lemonias) & $\sqrt{ }$ & $x$ & Wet soil \\
\hline 37 & $\begin{array}{l}\text { Common sergeant (Athyma } \\
\text { perius) }\end{array}$ & $\sqrt{ }$ & $\times$ & Mud, Rotten fruits \\
\hline 38 & $\begin{array}{l}\text { Common castor (Ariadne } \\
\text { merione) }\end{array}$ & $\sqrt{ }$ & $x$ & Rotten fruits, Rotten flowers \\
\hline
\end{tabular}




\begin{tabular}{|c|c|c|c|c|}
\hline 39 & Common sailer (Neptis hylas) & $\sqrt{ }$ & $\sqrt{ }$ & Mud, Wet sand, Rotten fruits \\
\hline 40 & $\begin{array}{l}\text { Leopard lacewing (Cethosia } \\
\text { cyane) }\end{array}$ & $\sqrt{ }$ & $x$ & Mud, Wet soil \\
\hline 41 & Commander (Moduza procris ) & $\sqrt{ }$ & $x$ & Mud, Rotten fruits, Wet soil \\
\hline 42 & $\begin{array}{l}\text { Common baron (Euthalia } \\
\text { aconthea) }\end{array}$ & $\sqrt{ }$ & $\sqrt{ }$ & $\begin{array}{l}\text { Bird dropping, Human sweat, } \\
\text { Lake side water (mud) }\end{array}$ \\
\hline 43 & Gaudy baron (Euthalia lubentina) & $\sqrt{ }$ & $\times$ & Rotten fruits, Wet sand \\
\hline \multicolumn{5}{|c|}{ Satyridae } \\
\hline 44 & $\begin{array}{l}\text { Lephca bushbrown (Mycalesis } \\
\text { lepcha) }\end{array}$ & $\sqrt{ }$ & $x$ & Wet soil \\
\hline 45 & $\begin{array}{l}\text { Common bushbrown (Mycalesis } \\
\text { perseus) }\end{array}$ & $\sqrt{ }$ & $\sqrt{ }$ & Carrion, Wet soil \\
\hline 46 & $\begin{array}{l}\text { Dark-branded bushbrown } \\
\text { (Mycalesis mineus) }\end{array}$ & $\sqrt{ }$ & $x$ & Rotten fruits, Wet soil \\
\hline 47 & $\begin{array}{l}\text { Common palmfly } \\
\text { (Elymnias hypermnestra) }\end{array}$ & $\sqrt{ }$ & $x$ & Bird dropping, Carrion \\
\hline 48 & $\begin{array}{l}\text { Spotted palmfly (Elymnias } \\
\text { malelas) }\end{array}$ & $\sqrt{ }$ & $\times$ & Dung, Wet soil \\
\hline 49 & $\begin{array}{l}\text { Common evening brown } \\
\text { (Melanitis leda) }\end{array}$ & $\sqrt{ }$ & $\sqrt{ }$ & $\begin{array}{l}\text { Carrion, Mud, Rotten fruits, } \\
\text { Rotten flowers, Wet soil }\end{array}$ \\
\hline 50 & $\begin{array}{l}\text { Dark evening brown (Melanitis } \\
\text { phedima) }\end{array}$ & $\sqrt{ }$ & $x$ & $\begin{array}{l}\text { Carrion, Rotten flowers, Wet } \\
\text { soil }\end{array}$ \\
\hline \multicolumn{5}{|c|}{ Hesperiidae } \\
\hline 51 & Grass demon (Udaspes folus) & $\sqrt{ }$ & $x$ & Bird dropping, Rotten flowers, \\
\hline 52 & Tree flitter (Hyarotis adrastus) & $\sqrt{ }$ & $x$ & $\begin{array}{l}\text { Bird dropping, Rotten flowers, } \\
\text { Sweat }\end{array}$ \\
\hline 53 & $\begin{array}{l}\text { Chestnut angle (Odontoptilum } \\
\text { angulata) }\end{array}$ & $\sqrt{ }$ & $\sqrt{ }$ & Wet soil \\
\hline \multicolumn{5}{|c|}{ Acraeidae } \\
\hline 54 & Tawny coster (Acraia violae) & $\sqrt{ }$ & $x$ & Wet sand \\
\hline
\end{tabular}

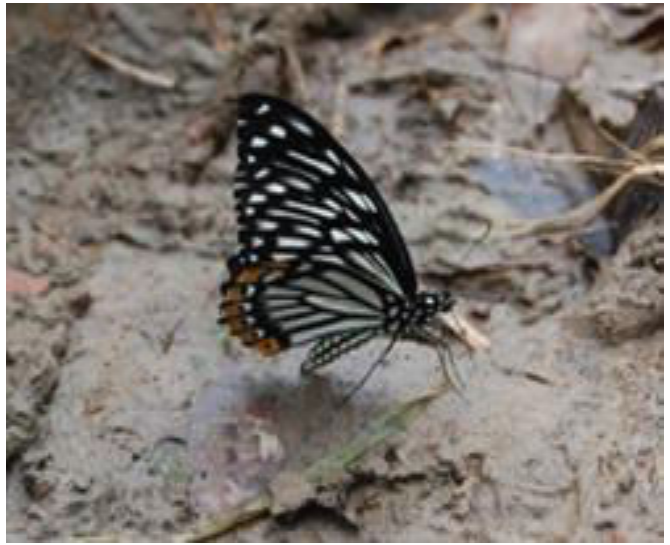

a. Common mime

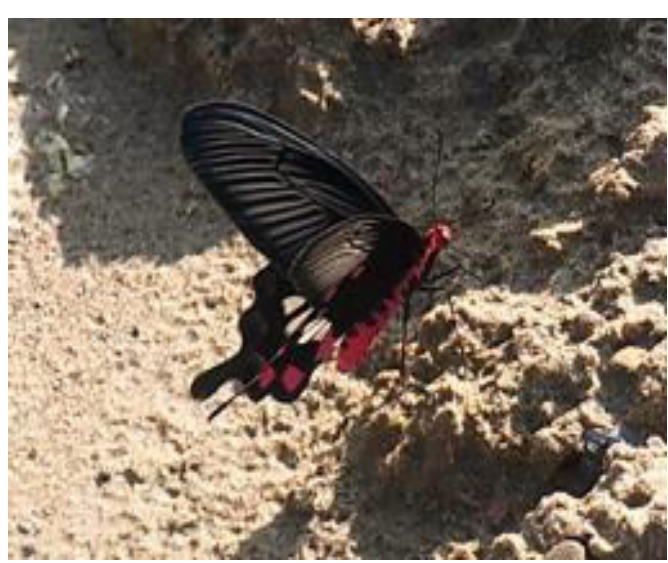

b. Common rose 


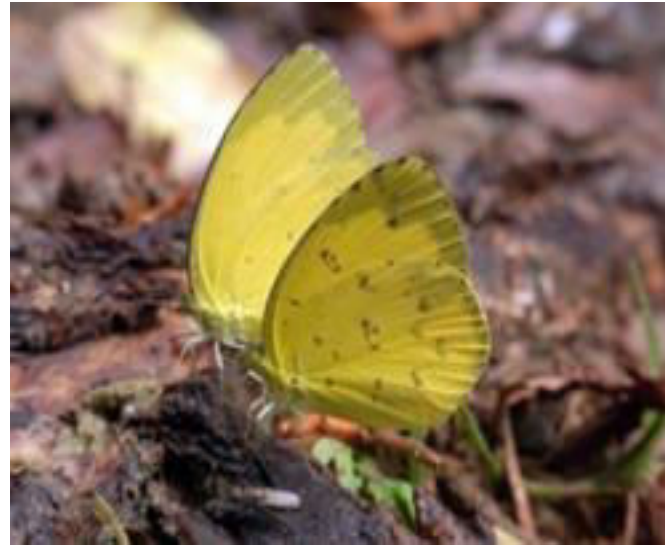

c. Common grass yellow

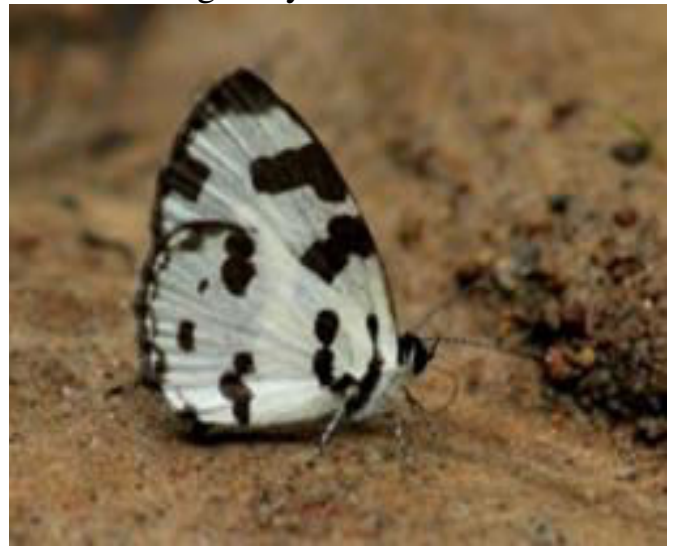

e. Angled pierrot

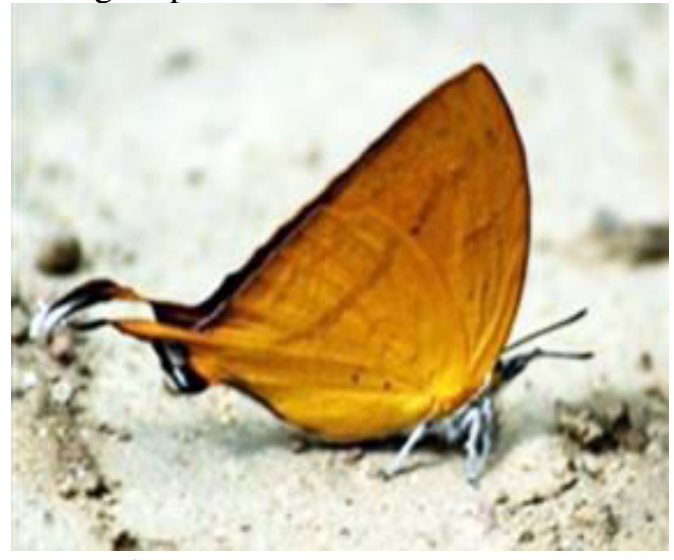

g. Yamfly

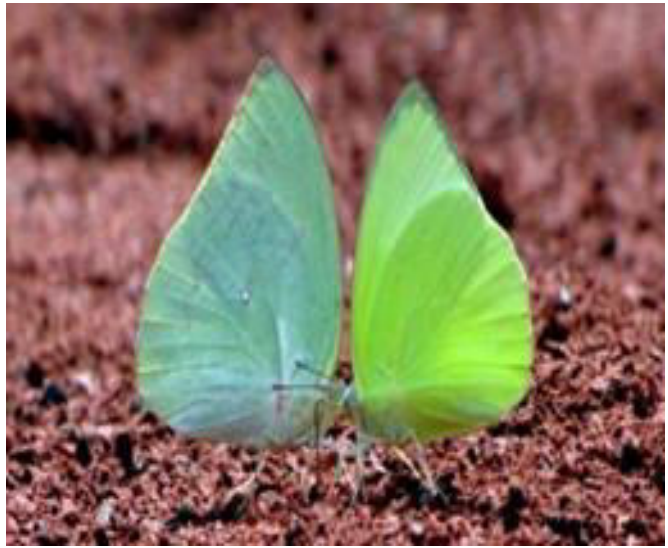

d. Common emigrant

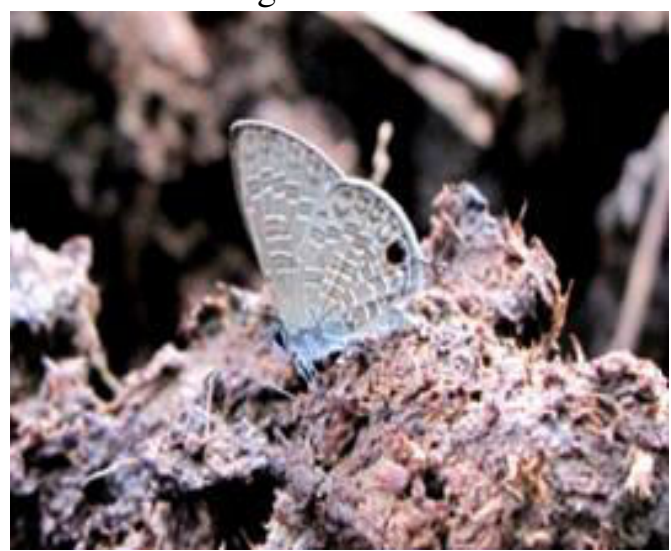

f. Common lineblue

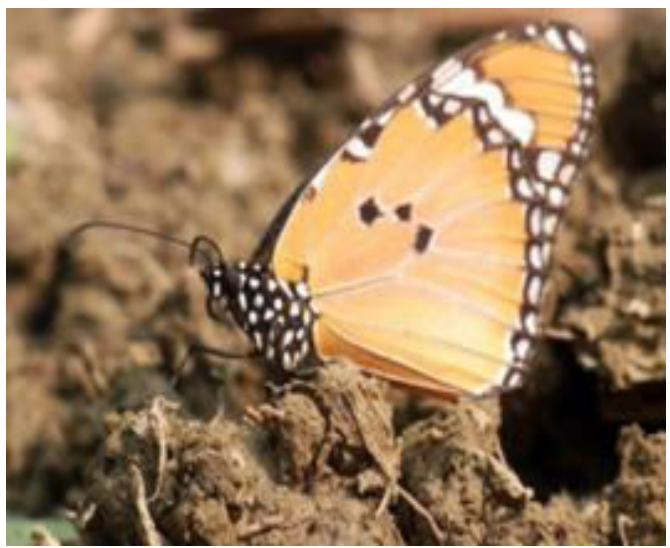

h. Plain tiger 

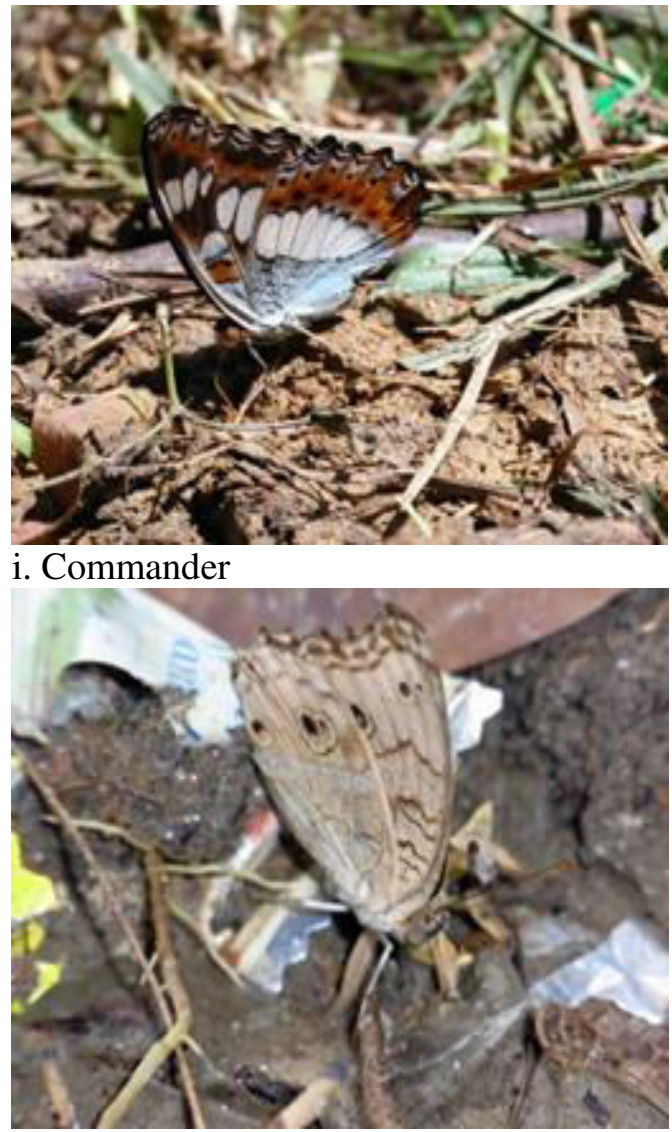

k. Peacock pansy

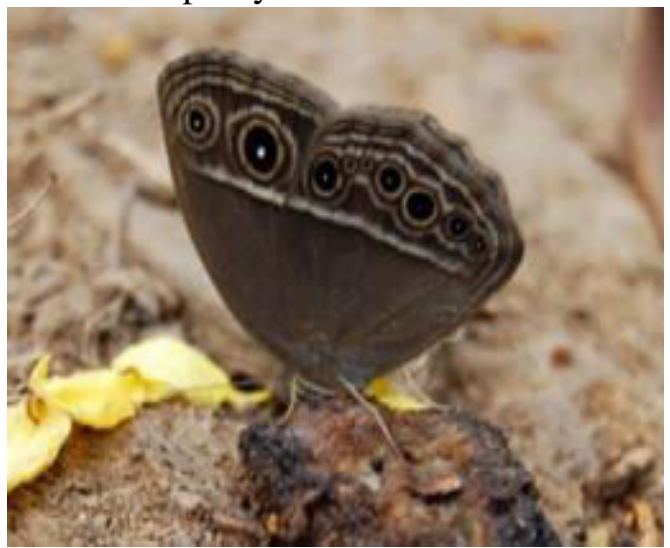

m. Common bushbrown

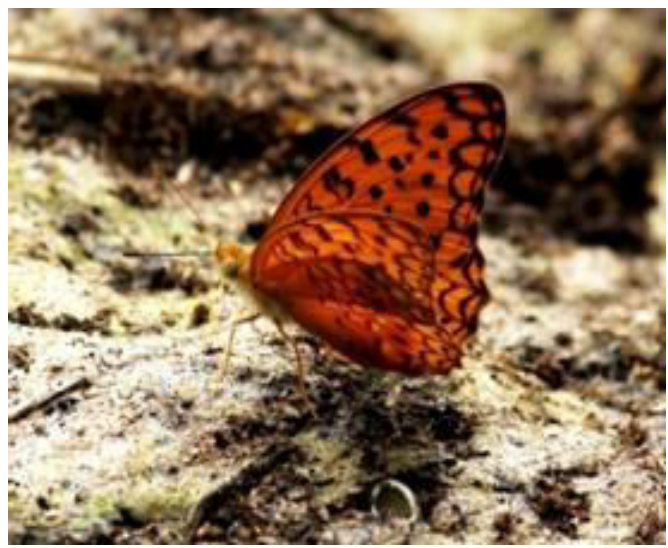

j. Common leopard

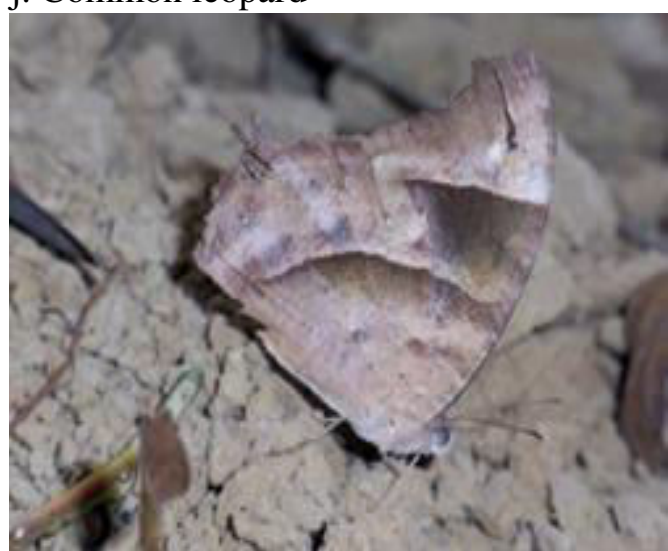

1. Common evening brown

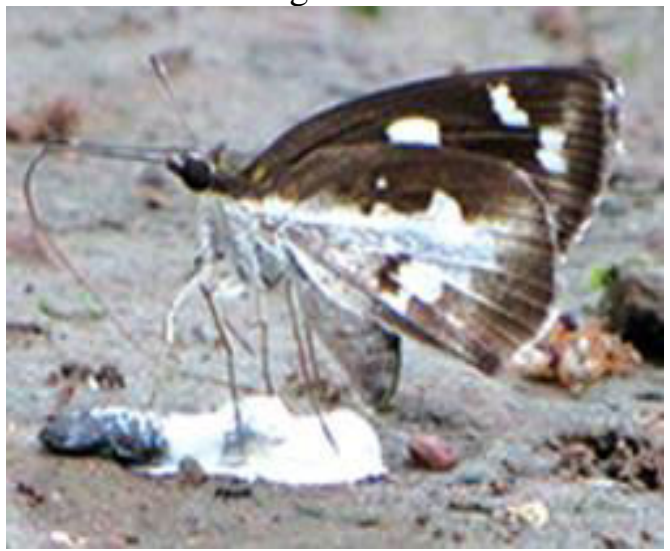

n. Grass demon 


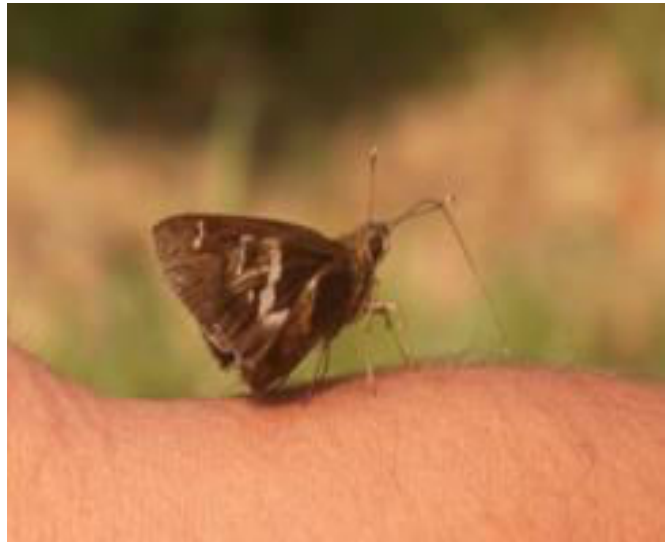

o. Tree flitter

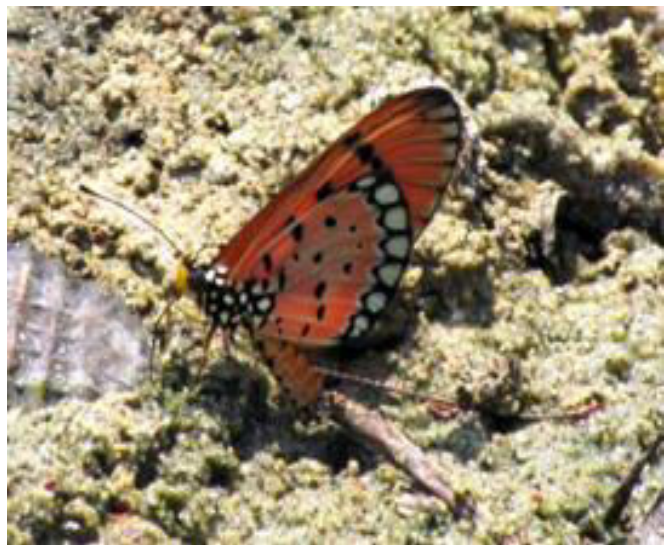

p. Tawny coster

Fig. 1. Puddling of butterflies in different sources in JU campus and BBR (a-p)
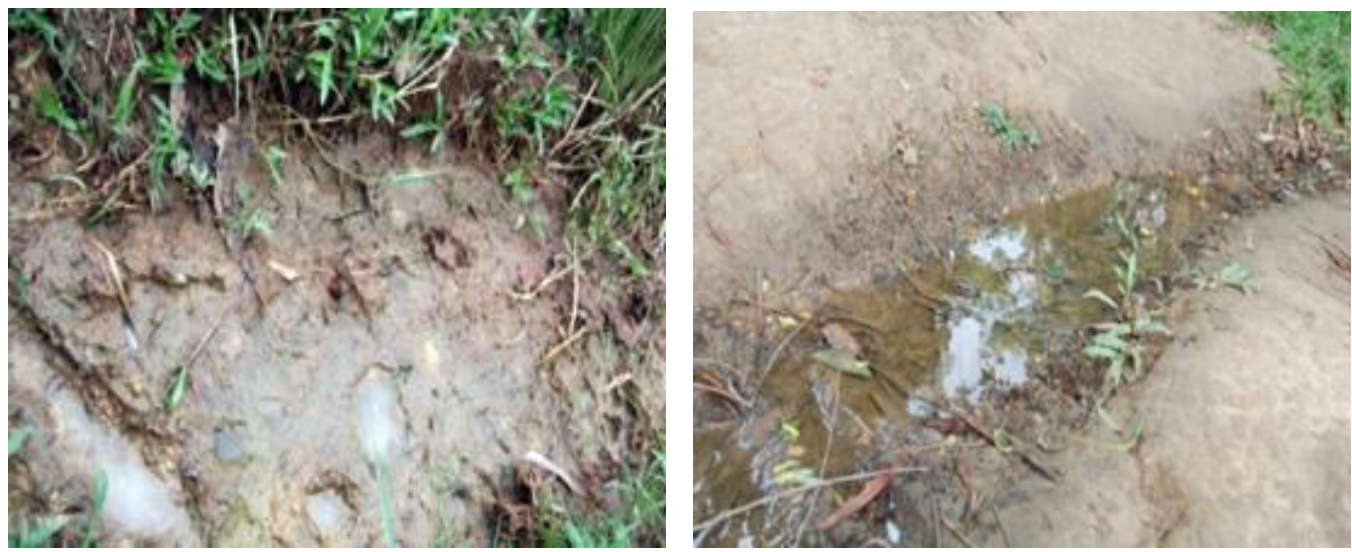

a. Mud at JU campus

c. Fresh dung at JU campus

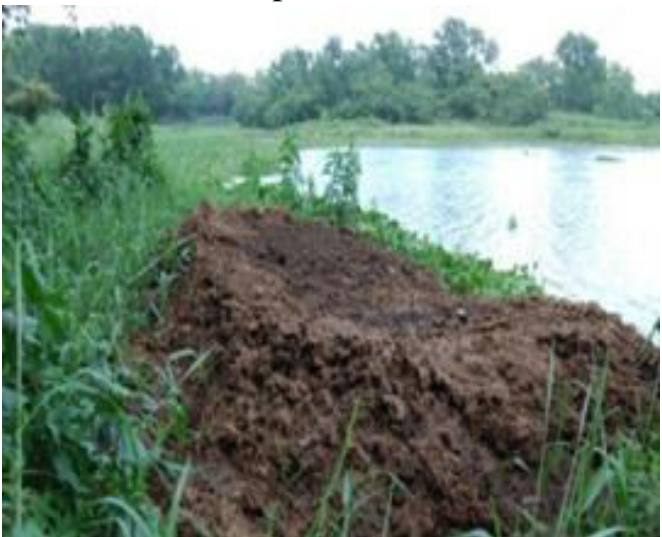

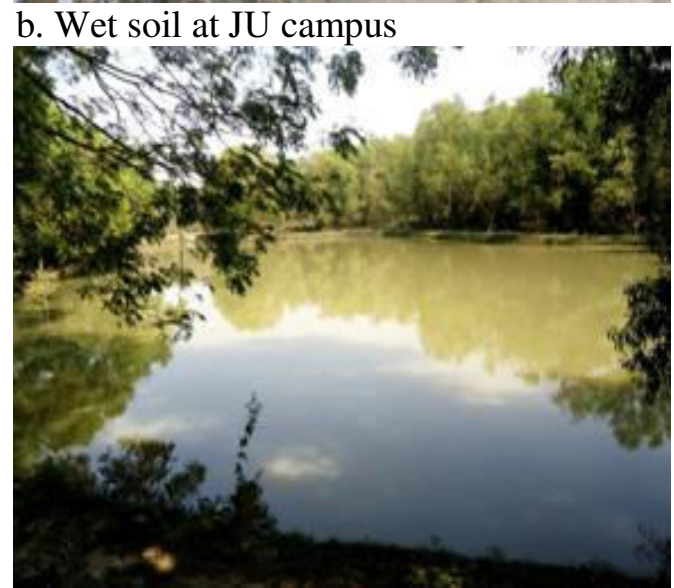

d. lake side water at JU campus 


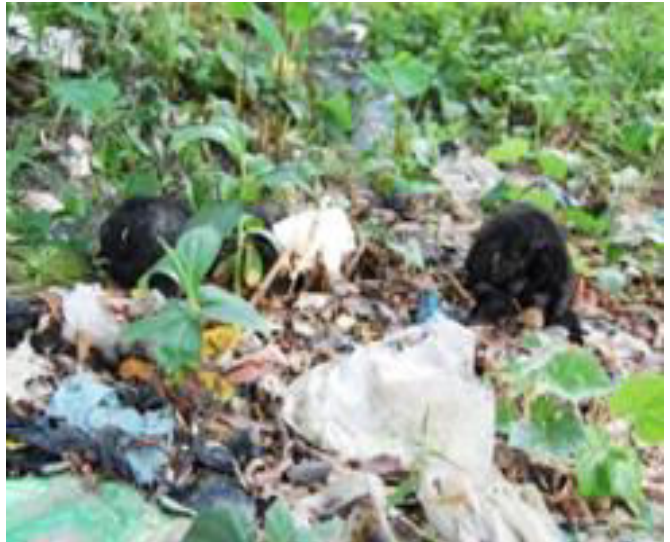

e. Carrion at JU campus

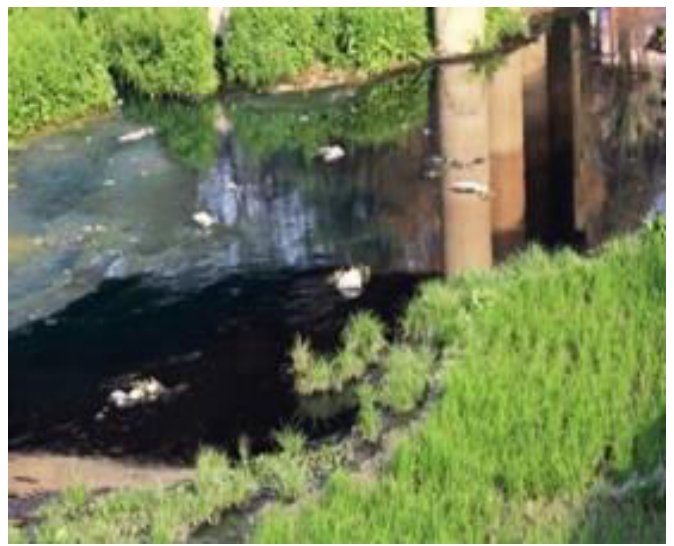

g. Bangshi River (site-1)

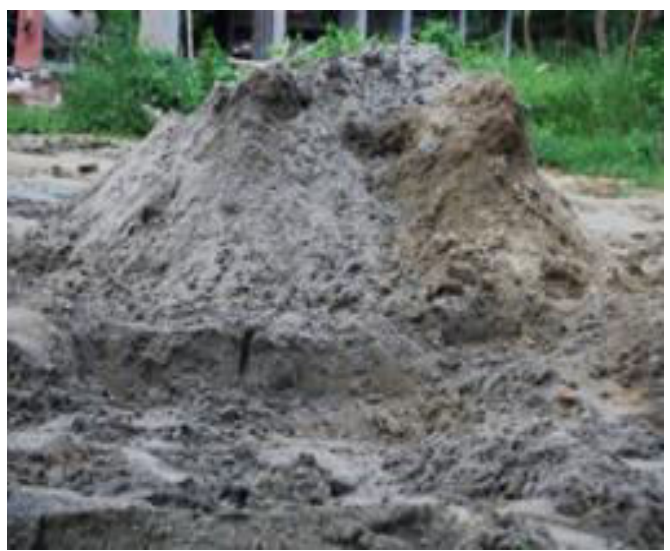

f. Wet sand at JU campus

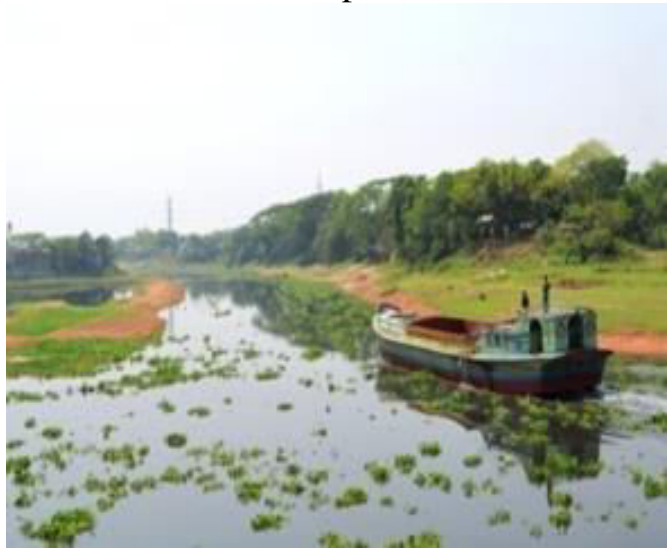

h. Bangshi River (site-2)

Fig. 2. Different puddling sources of butterfly at JU campus and bank of Bangshi river (a-h)

\section{REFERENCES}

Adler, P. 1982. Soil- and puddle-visiting habits of moths. J Lepid Soc. 36:161-173.

Adler, P.H. and Pearson, D.L. 1982. Why do male butterflies visit mud puddles? Can J Zool. 60: 322-325.

Ahmed, K.N. and Islam, W. 1987. A preliminary report on the butterfly, Euchrysops cnejas (F.) (Lepidoptera: Lycaenidae), a pest of black gram Vigna mungo (L.) from Bangladesh. Bangladesh J Zool. 15(1): 89-90.

Akter, F., Habib, M.S.A. and Hossain, M.M. 2015. Butterfly species diversity in spatial and temporal dimensions in Jahangirnagar University campus and its suburbs, Bangladesh. Jahangirnagar University J Biol Sci.4(1): 27-40.

Alam, M.S. and Ullah, G.M.R. 1995. A checklist of butterflies of Chittagong University. Bangladesh J. of Zool. 23(1): 111-112.

Alm, J., Ohnmeiss, T.E, Lanza, J. and Vriesenga, L. 1990. Preference of cabbage white butterflies and honey bees for nectar that contains amino acids. Oecologia.84:53-57.

Ameen, M. and Chowdhury, S.H. 1968. A systematic account of insect fauna of Dacca city and its suburbs. 1. Papilionidae (Butterflies), Lepidoptera. J Asiatic Soc Pak. 13(2): 221-227. 
Arms, K., Feeny, P. and Lederhouse, R. 1974. Sodium: stimulus for puddling behavior by tiger swallowtail butterflies. Science. 185: 372-374.

Baksha, M.W. and Chowdhury, J.H. 1985. Entomo-fauna in the forest of Bangladesh. 11. Papilionidae: Lepidoptera. Univ J Zool Rajshahi Univ. 2:53-60.

Bashar, M.A. 2014. Butterflies of Bangladesh-a broad approach for nature lovers. BCTF publications, EBBL, Dhaka-1000. pp 514.

Beck, J., Muhlenberg, E. and Fiedler, K. 1999. Mud-puddling behavior in tropical butterflies: in search of proteins or minerals?. Oecologia. 119: 140-148.

Bingham, C.T. 1905. Butterflies, Vol. I. Fauna of British India. Taylor and Francis, London. pp 511.

Bingham, C.T. 1907. Butterflies, Vol. II. Fauna of British India. Taylor and Francis, London. pp 480.

Boggs, C.L. and Jackson, L.A. 1991. Mud puddling by butterflies is not a simple matter. Ecol Entomol. 16:123-127.

Boggs, C.L. and Gilbert, L.E. 1979. Male contribution to egg production in butterflies: evidence for transfer of nutrients at mating. Science. 206: 83-84.

Candice, H. 2005.Beneficial in the Garden \& Landscape is an Earth- Kind Programme coordinated through Extension Horticulture at Texas A \& M University (http://aggiehorticulture.tamu.edu/galveston/beneficials/index.htm accessed on 10.06.16)

Chowdhury, S.H. and Mohiuddin, M. 2003. Butterflies of the eastern border of Bangladesh-a checklist. Rajshahi Univ J Zool. 22: 1-9.

Chowdhury, S.H. and Hossain, M. 2013. Butterflies of Bangladesh-A Pictorial Handbook (Revised and enlarged version). Skylark Printers, Dhaka, Bangladesh. pp 261.

Chowdhury, S.H. and Zethner, O. 1971. An interim report on results obtained in forest entomology section from July 1969 to August 1971. Forestdale News. 4 (1): 49-61.

Devries, P.J. and Walla, T.R. 2001.Species diversity and community structure in neotropical fruitfeeding butterflies. Biol. J. Linn. Soc.74: 1-15.

Drummond, B.A. 1984. Multiple mating and sperm competition in the Lepidoptera. In: Smith RL (ed) Sperm competition and the evolution of animal mating systems. Academic Press, New York. 291-396.

Erhardt, A. and Rusterholz, H.P. 1998. Do peacock butterflies (Inachis io L.) detect and prefer nectar amino acids and other nitrogenous compounds? Oecologia.117: 536-542.

Gilbert, L.E. 1972. Pollen feeding and reproductive biology of Heliconius butterflies. Proc Natl Acad Sci USA. 69: 1403-1407.

Hamer, K.C., Hill, J.K., Benedick, S., Mustaffa, N., Chey, V.K. and Maryati, M. 2006. Diversity and ecology of carrion- and fruit-feeding butterflies in Bornean rain forest. Journal of Tropical Ecology.22(1): 25-33.

Hossain, M., Shaheduzzaman, M., Howlader, A.J. and Chowdhury, S.H. 2003. Check List of Butterflies of Jahangirnagar University, Bangladesh. Bangladesh J Life Sci. 15(1):83-86.

Hossain, M.M., Habib, M.S.A., Islam, M.S., Akter, F., Khan, S.H., Sultana, S. and Rima, N. 2015. Record of Thaumantis diores and Gerosis sinica butterflies from Bangladesh. Bangladesh Journal of Zool. 43(2): 321-326.

Lai-Fook, J. 1991. Absorption of phosphorus from the spermatophore through the cuticule of the bursa copularix of the butterfly, Calpodes ethlius. Tissue Cell.23: 247-259.

Meme, A. 2014. Puddling of Butterflies in the campus of Jahangirnagar University and its suburbs. B.Sc Report, Dept of Zoology. Jahangirnagar University.

Neogi, A.K., Baki, M.A., Sadat, M.N., Selim, S.R. and Bhouiyan, N.A. 2014. Five new Records of Butterfly species from Dhaka, Pirojpur and Cox's Bazar Districts in Bangladesh. Journal of Entomology and Zoology Studies. 2(3): 197-200. 
O’Brien, D.M., Boggs, C.L. and Fogel, M.L. 2005. Physiological and Biochemical Zoology: Ecological and Evolutionary Approaches. The Amino Acids Used in Reproduction by Butterflies: A Comparative Study of Dietary Sources Using Compound-Specific Stable Isotope Analysis. Vol. 78, 5: 819-827.

Pivnick, K.A. and McNeil, J.N. 1987. Puddling in butterflies: sodium acts reproductive success in Thymelicus lineola. Physiol Entomol.12:461-472.

Razzak, M.A., Islam, A.T.M.F., Saifullah, A.S.M., Hossain, M.M., Shahjahan, R.M., Akira, Y. et al. 2007. A list of butterfly fauna in Jahangirnagar University Campus in Bangladesh. Nuclear Science and Applications. 16(2): 99-105.

Rima, N. 2012. Puddling of Butterfly in the campus of Jahangirnagar University. B.Sc Report. Dept of Zoology. Jahangirnagar University.

Shaheduzzaman, M. 1998. Status and diversity of butterflies of Bangladesh. M.Sc Thesis, Dept of Zoology, Jahangirnagar University.

Shefa, K. and Hossain, M.M. 2010. New records of butterflies from the Jahangirnagar University campus in Bangladesh. Bangladesh J. of Life Sci.22:20-27.

Smedley, S.R. and Eisner, T. 1995. Sodium uptake by puddling in a moth. Science.270:1816-1818.

Smedley, S.R and Eisner, T. 1996. Sodium: a male moth's gift to its offspring. Proc Natl Acad Sci USA.93: 809-813.

Talbot, G. 1978a. The Fauna of British India including Ceylon and Burma. Butterflies: Vol. I. Today and Tomorrow's Printers \& Publishers, New Delhi, India (2nd reprint). pp 660.

Talbot, G. 1978b. The Fauna of British India including Ceylon and Burma. Butterflies: Vol. I. Today and Tomorrow's Printers \& Publishers, New Delhi, India (2nd reprint). pp 506.

Wynter-Blyth, M.A. 1957. Butterflies of the Indian Region. Bombay Natural History Society, Bombay. pp 523. 